落ヨ防グタメ繾合シタル切創部，粘膜表皮次第 二箸殖シ之レガ次第二乳嘴狀二分岥シ，終二八 喉頭全體习充タスガ如キ大ナル乳嘴腫 リ。

而シテ之等ノ中 1 例ノ如キ切除側及ビ移殖側共 二乳嘴腫, 發生セル 認メタリ。

倘木此際周園組織二炎症々状及ビ血管控張，狀 著明ナリキ。

而シテ第 2 群ノ方が第 1 群二比シ成績良好ナ リ。

本實驗的研究ノ結果及ビ前記臨林例 $=ヨ$ リ喉頭 乳嘴腫，發生二關シテハ. 外傷モ大ナル關係 有スルコトヨ確メ得タリト信ズ。

33. 缺席。

\section{4. 直達鏡二依儿固有食道香室診療ノ}

\section{一症例}

小野 讓(東 京)

固有食道㷫室，臨䏫的診断例八比较的稀デア ル。ピーコック/統計デハ1930年迄，總類僅二 85 二過ギナイ。マタ1907年ョリ1925年迄メー

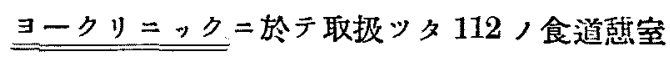
例中固有食道賏室八 2 例アルノミデアル。我國 二於テハ最近稻田.田宫ガ 4 例フ記載シデ居ル。

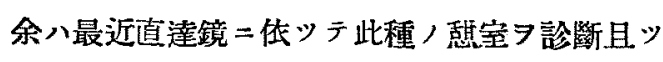
治療シ. 症狀的二至治シタ 1 例 フ經駗シタガ.

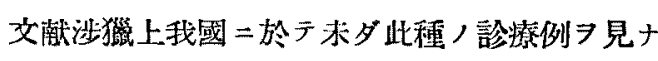
1 二低り茹二報告七ントスルモノデアル。

症例。西○久○. 51 歲。漁夫。主訴。胸骨社 異物感。現病歷。15歳八時. 船板掃除用, 䉆又 茶歖ニ入レテアッタ苛性曹迋液习茶ト思ツテ誤

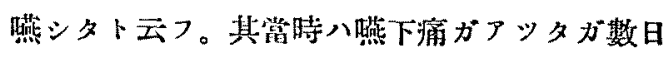
ニシテ恢復シタ。然ル二約 6 ケ月後通過障碍起 リ爾來每食事二際シ．茶或ハ湯ガナケレバ食事

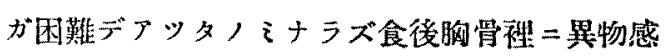

ガ常ニアッタノデ. 數人, 智療フ求メタガ何レ モ診斷不分明二終ツタトノ事デアル。我が來來 刃訪レシハ昭和 9 年 9 月28日デアル。 現症及ビ治療。體格中等度デ榮食八不良デナ ル。「バリウム」に依ル食道ノX線检查ノ結果食 道中部二款室アルラ認メタ。10月2日直徑 $8 \mathrm{~mm}$ 艮 $45 \mathrm{~cm}$ ノジャゥクソン式面澾鏡二㑈り食道检查

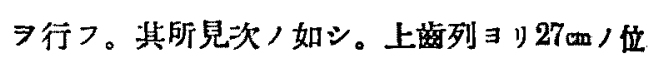
置デ正中線ヨリ少シク左偭，食道前壁二入口直 徑及ビ深サ共二約 $2 \mathrm{~cm}$ ，热室ノ存在 7 認メタ。 先ジ管先 7 此室內二笑り精查シタルニ. 粘膜” 激紅シ少量ノ粘液ノ潴溜 7 見. 、タ室ノ左壁二 著明, 搏動アルタ知ツタ。更二管先ノか向习獎 テ食道ノ檢查 腔ハ少シク虚痕性二狹管サレテ居ルラ認メタ。 印于直達鏡 $フ$ 利用シテ此狹窄部 7 擴大シタ。以 上操作所要時間ハ 7 分デアッタ。患者八郎日退 院シテ爾後器下障碍及ど胸部不快感八全り治䍂 シタト云ッテ居ル。(X線竄滇供覧)。

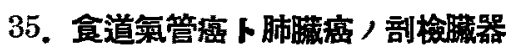
供覽村上 正 德(福 島) 48 歳/男子內科二テ阨結核トシテ喰療中病

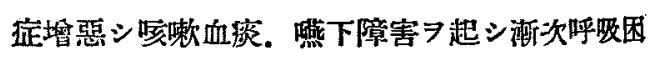
難 $モ$ 訴フルラ以テ常科）診 メテ污穢琹臭アリ喀痰粘棝ニシテ含泡性血液 混ズ。流動物八辛ジテ罴下シ得ルモ個形物八全

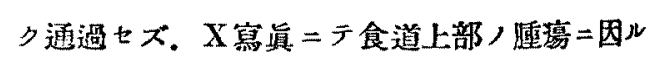
㷋窄アル尹知ル，喀痰检查二テ結核菌ハ證明七 ズ. 崩壤セル腫湯細胞习認ム。依テ食道氣管二 亘儿癌腫卜診定シ種々，治療ヨ施スモ效ナク透 二鬼籍二入ル。 死後 8 時間ニシテ自カラ新检二附ス。 先ヅ食道=於テハ入口部ヨリ下方約10 $\mathrm{cm}$ ，部ハ 


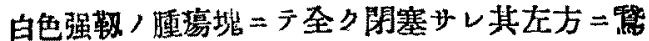

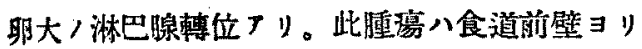
氣管後壁ニ及ビ氣管腔内＝現ハレ．氣管ハ只前 壁部二於テ： $i$ 僅二腔間 $\exists$ 保ツ程度二始ンド閉 塞サル狀態ニアリ。食道下部这＝氣管分岥部以 下ハ腫演ヨ見ザルモ其周圍淋巴腺ハ我石狀二肥

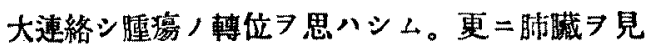
$ル=$ 雨肺共二殆ンド全沉二亘リテ白色胼胝樣， 肉贸ト化シ. 殊二雨下葉八高度ニシテ健康組織 八全ク見ラレザル猋態ナリ。之等食道，氣管． 淋巴腺及ビ肺ヨ組織學的二鏡檢スルニ何レモ扁 平上皮癌ナルヨ知レッ。

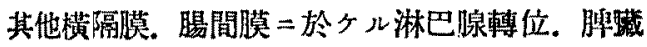

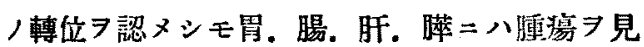
ズ。

却說始二食道. 氣管. 肺䁍卜巨大ナル同種 䔽二遭遇ゼシガ果シデ何レノ藏器ヨリ原發七シ カハ頌ル興味アル問題ナリシガ. 肉胑的鏡检的 二詳細ナル檢索ノ結果. 肺臟ノ原發癌ナル メ得タリ。果シテ然ラバ肺，何レノ部分ヨリ發 生セシモノカ. 之亦重要ナル問題ニシテ組織學 的检索，致フル所二低ラバ下葉，肺胞上皮ヨリ 起レルモノナルヨ推定シ得タリ。郎千本例八下 葉肺胞ヨリ渐次細氣管枝, 周園 7 侵シ淋巴道 7 經テ氣管二撗ガリ．更二氣管後壁ヨリ食道二或 延セルラ認裁シ得ルモノナリ。

肺／原發癌ハ稀ナラズ。サレド本例ノ如ク巨大 ナル肺癌卜其掂敞徑路/與味八病理學上極メテ

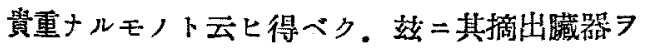
供筧スルモノサリ。

36. 耳鼻咽唉科領域矤患々者ノ唾液 $\mathrm{P}$ 數價 二及ボス影蠁竝二其踟牀的意味二就テ

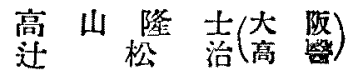

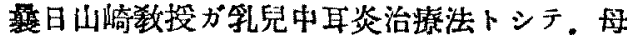

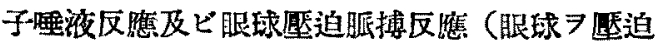
シ多少共脈搏ノ減少スル 7 陽性トシ。變化セザ ルラ陰性トス) フ指南トシテ. 藥物的。食触的

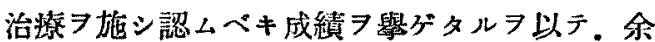

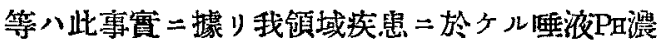
度及ビ眠球㻺迫脈搏反雇卜薬物的處置/疢患治 瘾二對スル效果，有無卜／關係 7 檢查スルコト ト七り。

此目的二對シ唾液 $\mathrm{PH}$ 漫度八P漫度試驗紙 7 用 ヒ. 一定，保件ノモト二. 即于检查前精神 $フ$ 安

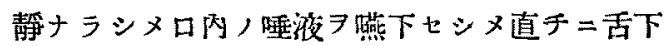

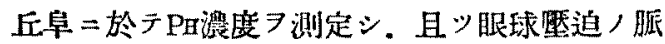
搏二及ボス影響，有無ヨ检シ。次イデ一定，處

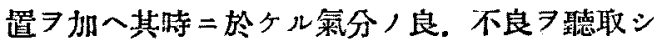
炎症ノ湉長 脈搏反雇 又影響，有㠫 7 精細二覞察七リ。

斯如シテ得タル今日迄ノ成緽ヨリそレバ一定疾 患過程二於ケル之等諸反應八吾人ガ今日迄想像 セシ以上ノ變化性 7 示シ。且ッ兩反應八常二必

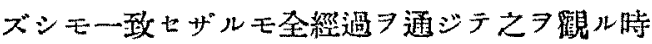
八一定,關係アルテ否定スル能ハズ。

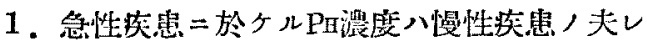
二比シテ上年シ．耳宛㭧二於テハ最モ上最シ 次イデ鼻疾㭧。咽喉口腔疾患ノ順序ナリ。(サ レド此處二面白キ八結核亚＝徽素八大體二於 テP渃度ハ上昇セザルコトナリ。)而シテ之等 疾腎八眠球壓迫脈搏反應陽性，時八陰性，時 二比シテ $\mathrm{P}$ 㟵度八大體上昇七ルモ㮯々ンツキ 日々ノ經過习斷片的二筧ル時八。必ズシモ一 定ノ關係ハ認メラレズ。

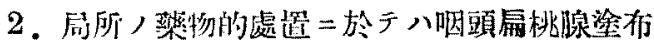

